\title{
Soil cover management: initial development of pear trees hosui cultivar and its effects on soil and weeds
}

\author{
Edina Costa Delonzek ${ }^{1}$ Renato Vasconcelos Botelho ${ }^{2}$, Marcelo Marques Lopes Muller ${ }^{3}$, \\ Cleber Daniel de Goes Maciel ${ }^{4}$, Aline José Maia ${ }^{5}$
}

\begin{abstract}
Soil management is a practice that influences the development of fruit trees. In this sense, the objective of this study was to evaluate the effect of different soil cover/mulching types on weed control and on the early development of pear trees Hosui cultvar. The experiment was conducted in two consecutive cycles: 2015/2016 and 2016/2017. Treatments consisted of the following soil covers in pear tree planting rows: natural cover, ryegrass straw intercropped with millet, pine sawdust, shading cover $(70 \%)$, rice husk, Curauá fiber and weeding. Soil infestation by weeds was evaluated in the springsummer period for two years, as well as the vegetative pear tree development (plant height and diameter and SPAD chlorophyll index). Managements using Curauá fiber and ryegrass straw + millet had the greatest suppression effects on weeds. The height and diameter of pear trees were smaller with natural cover and pine sawdust, while higher plant growth was observed with Curauá fiber and with weeding. Higher SPAD indexes was observed with Curauá fiber, weeding and ryegrass + millet. Curauá fiber also stood out for $\mathrm{Fe}$ and $\mathrm{Mn}$ leaf contents, while $\mathrm{Zn}$ contents were higher with ryegrass + millet and rice husk. Ryegrass straw + millet and rice husk can be highlighted for the chemical attributes of soil fertility and soil macrofauna indexes. It could be concluded that Curauá fiber and azevem + millet weed control weeds in the orchard, thus promoting better initial development of pear trees Hosui cultivar. Index terms: Pyrus spp., spontaneous plants, agroecology, soil fertility, sustainability.
\end{abstract}

\section{Manejo da cobertura do solo: desenvolvimento inicial de pereiras cv. Hosui e efeitos sobre o solo e plantas daninhas}

Corresponding author: dinadelonzek@yahoo.com.br

\section{Received: July 03, 2018}

Accepted: December 05, 2018

Copyright: All the contents of this journal, except where otherwise noted, is licensed under a Creative Commons Attribution License.

\begin{abstract}
Resumo - O manejo do solo é uma prática que pode ter marcante influência no desenvolvimento de frutíferas. Neste sentido, o objetivo do trabalho foi avaliar o efeito do uso de diferentes tipos de cobertura de solo no controle de plantas daninhas e no desenvolvimento inicial da pereira cv. Hosui. O experimento foi conduzido durante dois ciclos consecutivos: 2015/2016 e 2016/2017. Os tratamentos consistiram nas seguintes coberturas de solo na linha de plantio das pereiras: cobertura natural, palhada de azevém consorciado com milheto, serragem de pínus, tela de sombreamento (70\%), casca de arroz, fibra de curauá e capina. A infestação do solo por plantas daninhas foi avaliada no período de primavera-verão, durante dois anos, assim como o desenvolvimento vegetativo da pereira (altura e diâmetro de plantas e índice de clorofila SPAD). Os manejos com fibra de curauá e com palha de azevém+milheto tiveram os maiores efeitos de supressão sobre as plantas daninhas. A altura e o diâmetro das pereiras foram menores com cobertura natural e serragem de pínus, havendo maior crescimento das plantas com a fibra de curauá e com capina. Índices SPAD mais elevados ocorreram com a fibra de curauá, capina e azevém+milheto. A fibra de curauá também se destacou quanto aos teores foliares de Fe e Mn, enquanto os teores de $\mathrm{Zn}$ foram maiores com azevém+milheto e casca de arroz. A palhada de azevém+milheto e a casca de arroz destacaram-se quanto aos atributos químicos de fertilidade do solo e quanto aos índices de macrofauna edáfica. Conclui-se que a fibra de curauá e palhada de azevem+milheto controlam plantas daninhas no pomar, promovendo o desenvolvimento inicial da pereira cv. Hosui.
\end{abstract}

Termos para indexação: Pyrus spp., plantas espontâneas, agroecologia, fertilidade do solo, sustentabilidade.

\footnotetext{
'Bióloga. Mestre em Produção Vegetal. Universidade Estadual do Centro-Oeste - UNICENTRO. Guarapuava-PR. Brasil. E-mail: edinadelonzek@yahoo.com.br (ORCID 000000026809 8871)

${ }^{2}$ Eng. Agr. Doutor. Professor Adjunto. Departamento de Agronomia, Universidade Estadual do Centro-Oeste - UNICENTRO. Guarapuava-PR. Brasil. E-mail: rbotelho@unicentro.br(ORCID 0000-0001-9580-2572)

${ }^{3}$ Eng. Agr. Doutor. Professor Adjunto. Departamento de Agronomia, Universidade Estadual do Centro-Oeste - UNICENTRO. GuarapuavaPR. Brasil. E-mail: mmuller@unicentro.br (ORCID 0000-0002-5466-2398)

${ }^{4}$ Eng. Agr. Doutor. Professor Adjunto. Departamento de Agronomia, Universidade Estadual do Centro-Oeste - UNICENTRO. Guarapuava-PR. Brasil. E-mail: cmaciel@unicentro.br (ORCID 0000-0003-3222-2946)

${ }^{5}$ Eng. Agra. Doutora em Proteção de Plantas. Departamento de Agronomia, Universidade Estadual do Centro-Oeste - UNICENTRO. Brasil. E-mail: alymaia2005@gmail.com(ORCID 0000-0003-0233-9481)
} 


\section{Introduction}

The area and economic expression of pear (tree) cultivation in set state of Paraná, as well as in other areas of Brazil is still small, although it has shown some growth in recent years, reaching annual production of approximately 14900 tons in an area of 1248 hectares (FAO, 2016).

According to Pitelli (1987), weeds can indirectly interfere with the growth and production of perennial crops by competing for essential resources to their development. In addition, the release of allelopathic substances may occur under certain conditions (GOMES JR.; CHRISTOFFOLETI, 2008), and they can also act as intermediary hosts of pests and pathogens, thereby promoting significant delay in crop development (LEITE JÚNIOR; MOHAN, 1990; BENBROOK, 2009).

A study carried out by Pelizza et al. (2009) evaluating the initial growth of apple plants in an orchard verified that the presence of weeds in the planting row affected crop growth, with reduction in plant height and diameter, evidencing interference in the growing period of apple trees.

Weeding is the simplest and oldest form of weed control; however, it requires considerable manpower and leaves the soil uncovered, making it susceptible to erosion. In addition, mechanical weeding can damage the root system of the pear tree. Another option that can be pointed out among the most used management practices for weed control in orchards is mowing/cutting, which controls plant development; however, unlike weeding, it leaves a vegetative layer that protects the soil (MATHEIS et al., 2006).

Soil covers can be an alternative to the use of agrochemicals for weed control in orchards, especially in terms of sustainability in production systems. When cover crops are used, fast-growing species with good biomass production should be prioritized, since the main role of soil cover in terms of suppressing natural vegetation depends on the initial establishment of cover plants/crops, population density and waste produced (CARVALHO; VARGAS, 2004).

Soil cover or "mulching" can also be achieved using materials such as black plastic, shading cover, rice husk, pine sawdust and vegetable fibers. Regardless of material used, cultivation management can reduce the use of herbicides with ecological benefits and reduce production costs, with better use of natural resources (CARVALHO; VARGAS, 2004).

Curauá (Ananas erectifolius) is a plant belonging to the Bromeliaceae family and native to the Amazon region, which fibers have been used to reinforce polypropylene matrices in composites used in domestic vehicles in the national market (ROSA et al., 2012). Its use is also being tested in the performance of cement composites used in civil construction (BELTRAMI, 2014), and as a vegetable fiber, it can also be studied regarding its use as soil cover.

Proper soil coverage management can improve physical, chemical and biological soil properties (PELIZZA et al., 2009), which contributes to the production of fruit species (RAGOZO et al., 2006), thus deserving attention in agroecological production systems (GOH et al., 2000; ZINN et al., 2018). However, little is known about the effects of soil cover management in terms of weed occurrence and its competition with pear tree cultivation in Southern Brazil, and the efficiency of this practice in weed management and pear tree growth response may vary.

The objective of this study was to evaluate different soil cover management materials on weed infestations in the planting row, on soil attributes and on the growth and nutrition of pear trees Hosui cultivar.

\section{Materials and Methods}

The experiment was carried out in a commercial orchard of pear trees Hosui cultivar in the Municipality

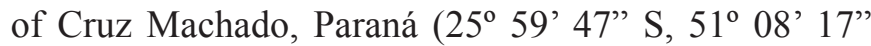
$\mathrm{W}$; altitude of 1094 masl). According to the Köppen classification system, the climate of the region is classified as humid subtropical mesothermal $(\mathrm{Cfb})$ without dry season, with warm summers and moderate winters. The soil of the experimental area is a Brazilian Oxisol (Latossolo Bruno distroférrico) (EMBRAPA, 2013). Pear seedlings grafted on Pyrus calleriana rootstock were planted on 10/2/2015 according to $3.0 \times 2.5 \mathrm{~m}$ spacing and managed in the central leader system. The experiment was conducted in the 2015/2016 and 2016/2017productive cycles.

The experimental design was randomized blocks with four replicates. Each plot consisted of four plants in rows, considering the area of the two central plants of each plot as a useful area for all evaluations. Treatments were: natural cover (spontaneous native species vegetating in the growing area); ryegrass straw + millet cover (Lolium multiflorum, $35,500 \mathrm{~kg}$ of straw per ha- $\left.{ }^{1}\right)$ associated with millet straw (Pennisetum glaucum, 40,000 kg per ha- ${ }^{1}$ ); pine sawdust (Pinus elliottii var. elliottii); shading cover (70\% sunlight blockage, Sol Pack Ltda, Osasco, SP, Brazil); rice husk (in decomposition); Curauá fiber (pressed, Pematec Triangel do Brasil Ltda, Santarém, PA, Brazil) and manual weeding (maintained the plot without any living vegetation cover throughout the whole cycle; however, with cover of dead weeds rotated during weeding). Treatments were installed in the plant row in a 1 $\mathrm{m}$ wide range. Curauá fiber and shading cover were fixed to the sides with a layer of soil and wire. Dead covers of ryegrass straw + millet, pine sawdust and rice husk were applied with a $10 \mathrm{~cm}$ thickness layer on the ground. Covers were replenished quarterly in the vegetative growth cycle 
of each period for all treatments, except for Curauá fiber, which was annually supplied. Soil was cleaned prior to the installation of soil covers. Weeding was performed prior to the installation of each of treatments in order to standardize them, removing residues.

The orchard management followed procedures recommended for organic systems (BRASIL, 1999) using Bordeaux syrup, lime sulfur and neem oil as phytosanitary treatments. Among orchard rows, the only operation performed was mechanized mowing to manage weeds, carried out at different intervals according to plant growth speed. Liming and fertilization were performed according to technical recommendations for the crop in Brazil (CENTELLAS-QUEZADA et al., 2003) according to soil analysis using dolomitic limestone, natural phosphate and avian litter 30 days prior to crop implantation.

More than $50 \%$ of weeds were in the reproductive stage at 75 days after implementing soil covers of 2015/2016 and 2016/2017 cycles, when the aerial parts of these plants were collected from the useful area of $0.5 \mathrm{~m}^{2}$ of plots using a square metal frame $(0.50 \times 0.50 \mathrm{~m})$. Weeds from each treatment were collected separately, conditioned in paper bags and dried in a forced air circulation oven for 72 hours at $65^{\circ} \mathrm{C}$ for later weighing (plant dry mass).

Pear tree growth was monthly evaluated between November 2015 and March 2017 (except between April and September due to dormancy), by measuring plant height from the soil surface to the apex of the highest branch, and also by measuring stem diameter at $10 \mathrm{~cm}$ above plant grafting line. Relative chlorophyll content data (SPAD) were determined using four readings from a Minolta SPAD-502 chlorophyll meter in the middle part of the leaf, at two points on each side of the central vein on the adaxial side in 10 leaves per plot. Determinations were taken after full budding in the second crop cycle in the months of November and December (2016) and January (2017). Covers were then applied using leaves of the middle third of plants after 4 p.m., since temperatures are milder.

Leaves for chemical analysis were also collected in the second cycle, for the determination of macro $(\mathrm{N}, \mathrm{P}$, $\mathrm{K}, \mathrm{Ca}$ and $\mathrm{Mg}$ ) and micronutrients ( $\mathrm{Fe}, \mathrm{Mn}, \mathrm{Zn}, \mathrm{Cu}$ and B). Ten leaves per plot were sampled in the second half of January, removed from the middle part of shoots, which were then immersed in solution with detergent (1\%), rinsed with distilled water, dried at $65^{\circ} \mathrm{C}$ until constant weight, ground and preserved (BASSO et al., 2003). At the same time, soil samples were collected from 0-20 cm depth layers. Chemical analyses of soil and leaves were carried out according to EMBRAPA (2009).

Still during the second cycle, soil macrofauna was evaluated based on the excavation of soil monoliths (25 $\mathrm{cm} \times 25 \mathrm{~cm}$ wide, $20 \mathrm{~cm}$ deep), according to standard protocol of the Tropical Soil Biology and Fertility (TSBF) Program (ANDERSON; INGRAM, 1993). Each monolith was collected using a straight blade about $20 \mathrm{~cm}$ away from the plant until the depth of $0-20 \mathrm{~cm}$, and the material was stored in plastic bags. In the laboratory, samples were scattered in plastic trays and inspected using spatulas for screening organisms, which were stored in bottles with $70 \%$ alcohol for later counting and identification. After counting, total density (number of individuals per square meter), Margalef richness index, Pielou evenness index, and Shannon diversity index were determined (ODUM, 1988).

Data were submitted to analysis of variance and means were compared by the Student Newman-Keuls test at 5\% probability level using SISVAR software (FERREIRA, 2014).

\section{Results and discussion}

The occurrence of weeds was affected by treatments at 75 days after application of soil covers for both production cycles with differences for the dry mass of weeds (Table 1 ). In the 2015/2016 cycle, ryegrass + millet cover resulted in lower weed dry mass production compared to treatments with natural cover, pine sawdust, shading cover and rice husk, while Curauá fiber and weeding fully suppressed weed infestation.

In the 2016/2017 cycle, Curauá fiber was again equal to weeding, suppressing any weed growth. Among treatments with infestation, mean dry mass was lower for ryegrass + millet, pine sawdust and shading cover in relation to rice husk, which resulted in higher dry mass, however, these treatments did not differ statistically from natural cover.

In addition, lower weed growth was observed in the second implementation period, which may be related to the period with the lowest rainfall intensity in the 2016/2017 cycle (SIMEPAR, 2017), and to the residual effects of cover suppression due to light filtration and the quantity and quality of the length of light waves, in addition to temperature maintenance with smaller oscillations (PITELLI, 1997; THEISEN; VIDAL, 1999). Some studies have shown that soil covers reduce the bulk mass of a weed population over the period (MARTINS, 1995; MESCHEDE, 2007).

Among covers, the best results were verified for Curauá fiber, which was as efficient as weeding for weed control. This result is possibly related to the total shading of the soil surface throughout the evaluation period, which may have influenced the dynamics of the weeds' seed bank (VOLL et al., 2005). With light intensity reduction in light intensity, the soil thermal and water amplitude possibly played a significant role, inhibiting the germination of weed seeds.

The response of pear trees to soil coverage showed 
differences among treatments for variables pear tree height and stem diameter in both periods (Table 2). The lowest averages for both variables evaluated were generally observed for cover with pine sawdust for both cycles, with no differences from natural cover treatment. The highest averages were found for Curauá fiber cover, which did not differ from weeding treatment for most evaluations. The other treatments presented intermediate values; however, with significant differences in relation to natural cover only for plant height in the second cycle (2016/2017) for treatments with ryegrass straw + millet, rice husk and shading cover.

Pinus sawdust showed reduction in the initial development of pear tree probably due to the presence of phenolic compounds (lignin content of 25-30\%) in the sawing of pine trees, and as its decomposition is slower, the allelochemical effect remains for a longer period of time (Almeida 1991; Carvalho et al., 2009). While the effectiveness of the use of Curauá cover in weed management and in the development of pear tree verified in this work may be related to its high resistance, lightness and recyclability. According to Behrens 1999, Curauá fibers presented mass composition from 0.6 to $1.2 \%$ of ash, cellulose between 69.0 and $74.1 \%$, hemicellulose between 19.0 and $21.1 \%$ and lignin between 1.0 and $2.2 \%$, and these values may vary according to the planting site, aging time of fibers and Curauá variety (purple or white).

Regarding the chlorophyll level evaluation (SPAD index) of pear tree leaves in the second vegetative cycle, significant differences were observed among treatments in the three seasons (Table 2). Cover with ryegrass straw + millet had the highest average in November and December 2016, not differing from treatments with Curauá fiber and weeding in the evaluation performed in December. However, in the evaluation carried out in January 2017, treatments with Curauá fiber and weeding reached the highest rates, followed by cover with ryegrass straw + millet, which surpassed cover with rice husk; while natural pine sawdust cover and shading cover presented the lowest indexes.

These treatments presented higher nitrogen content in leaves, ranging from 21 to $31.5 \mathrm{~g} \mathrm{~kg}^{-1}$, although these values fall into classes of contents above normal (CQFS 2004) for the pear tree crop in Brazil, there was no difference among treatments. Nitrogen participates in important metabolic processes in the plant such as photosynthesis and chlorophyll pigments, possibly explaining the decrease in the SPAD index over the evaluation months.

The $\mathrm{P}$ content in leaves (Table 3 ) varied according to treatments, in which Curauá fiber resulted in higher content in relation to shading cover; however, all treatments had ideal leaf nutrient contents for this crop (BASSO et al., 2003). This fact can be attributed to the scattering of natural phosphate in the orchard area. The use of scattered phosphate and incorporated into natural soil has residual effect for longer periods and thus provides better condition for growing fruit trees within agroecological agriculture standards (OLIVEIRA et al., 2013).

$\mathrm{Ca}$ and $\mathrm{K}$ content on pear tree leaves were not affected by soil cover and management (Table 3 ). This is explained by the fact that there were adequate $\mathrm{Ca}$ and $\mathrm{K}$ levels in the soil (Table 4). Regarding foliar Mg levels, no response to soil cover treatments was evidenced, remaining below adequate levels (of 2.50-4.50 $\mathrm{g} \mathrm{kg}^{-1}$ and 20-100 mg kg-1, respectively) (BASSO et al., 2003).

Significant differences among treatments were found for micronutrients ( $\mathrm{Cu}, \mathrm{Fe}$ and $\mathrm{Zn}$ ) (Table 3). $\mathrm{Cu}$ levels were below adequate levels (5.0 to $30.0 \mathrm{mg} \mathrm{kg}^{-1}$ ) for treatments with natural cover, pine sawdust, shading cover and rice husk, being only sufficient in treatments with weeding and ryegrass + millet and Curauá fiber. Higher content in treatment with weeding in relation to natural cover was observed.

In relation to $\mathrm{Fe}$, Curauá fiber, weeding and pine sawdust treatments showed levels within normal range ( 0 to $250 \mathrm{~g} \mathrm{~kg}^{-1}$ ), in which Curauá fiber cover provided levels significantly higher than natural cover treatment. However, for $\mathrm{Zn}$, treatments with Curauá fiber and weeding presented levels lower than normal range (20 to $100 \mathrm{mg} \mathrm{kg}^{-1}$ ), while the other treatments presented adequate levels for this crop (BASSO et al., 2003; CQFS$\mathrm{RS} / \mathrm{SC}$, 2004). Ryegrass + millet and rice husk stood out, presenting significantly higher levels compared to shading cover treatment, which in turn was higher than weeding. Natural cover, pine sawdust and Curauá fiber did not differ from ryegrass + millet and rice husk, or from shading cover.

In general, Hosui cultivar has little ability to absorb micronutrients. These results are in agreement with those obtained by Botelho et al., (2010), who studied the nutrient content in different pear tree cultivars and verified that Hosui, cultivar presented leaf $\mathrm{Cu}, \mathrm{Zn}$ and $\mathrm{B}$ contents below normal for the crop.

In relation to organic matter $(\mathrm{OM}), \mathrm{P}, \mathrm{Ca}^{2+}$ and $\mathrm{K}^{+}$ in the soil, significant differences were found among the different managements (Table 4). Higher OM content was found for rice husk cover, which differed from natural cover, ryegrass + millet and shading cover, which values were higher than those of pine sawdust cover. The fact that the weeding treatment presented high OM content may be related to the incorporation of natural cover by soil rotation. Treatment with pine sawdust has lower MO content, possibly because it presents substances that take long period to decompose (CARVALHO et al., 2009).

Soil pH ranged from 4.1 to 5.6 (Table 4), with significant differences among treatments. Cover with ryegrass straw + millet and rice husks was superior than weeding, which in turn surpassed shading screen. Differences in soil $\mathrm{pH}$ of the soil due to treatments may 
be due to the release of organic compounds from the decomposition of residues. The addition of vegetable residues may increase $\mathrm{pH}$ prior to humification by promoting the complexation of $\mathrm{H}$ and $\mathrm{Al}$ with vegetable residue compounds, which makes $\mathrm{Ca}, \mathrm{Mg}$ and $\mathrm{K}$ more free in solution, increasing CTC saturation, due to these cations of basic reaction (PAVINATO; ROSOLEM, 2008).

Treatment with ryegrass + millet showed higher phosphorus content, however, it did not differ from the other treatments, except for shading treatment, which resulted in significantly lower P content (Table 4). This increase in soil $\mathrm{P}$ availability may be due to the presence of $\mathrm{P}$ in plant residues or competition of organic residues by soil exchange sites (RHEINHEIMER and ANGHINONI, 2001). Soil that received shading screen had lower phosphorus content, possibly due to its lower $\mathrm{pH}$, which makes $P$ less available in soil and plant (ZAMBOLIM, et al., 2012), which does not add soil residue and if it blocks in $70 \%$ sunlight.

For soil $\mathrm{Al}^{3+}$ there was no statistical difference among treatments (Table 4). In soil management with vegetation cover (natural vegetation, azevem + millet, curuáu and weeding), it is possible that soil $\mathrm{pH}\left(\mathrm{CaCl}_{2}\right)$ presented values above 5.0, a situation that greatly reduces soil solubility. In an experiment with coffee crop, Pavan et al. (1986) verified that the $\mathrm{Al}^{3+}$ contents decreased with soil cover maintenance, characterized by cover crops in the planting line. Another explanation can be the release of $\mathrm{NH}_{3}$ during the plant material decomposition, causing precipitation of $\mathrm{Al}$ as hydroxide, as complexing reactions of Al with organic compounds (surface adsorption, chelation and other reactions) are present in larger proportions in treatments with high organic matter content (MENDONÇA, 1995)

The $\mathrm{Ca}^{2+}$ content was significantly influenced by treatments (Table 4). The low values observed with natural cover was only above ryegrass + millet straw, which in turn was surpassed by the other treatments. This reduction may be related to the increase in crop demand due to aerial shoot growth and root system expansion (PAVINATO et al., 2009). The other treatments presented smaller number of plants, consequently less nutrient extraction. Similar effect was observed for $\mathrm{Mg}$, and all treatments presented higher content compared to natural cover.

Comparing treatments, significant differences were also observed for $\mathrm{K}^{+}$levels (Table 4). Natural cover presented the lowest soil $\mathrm{K}^{+}$levels, differing from the others and from ryegrass + millet cover, which was superior to all other treatments, thus demonstrating potential to be used as pear tree cover in soils with low $\mathrm{K}^{+}$availability. The highest soil $\mathrm{K}^{+}$concentration is related to the root system of plants, which promotes the cycling of this element in the soil, since the absorption of $\mathrm{K}^{+}$by deeper roots can be transferred to more superficial layers (BRUNETTO et al., 2015).
Treatment with the highest density of soil macrofauna individuals per square meter (indiv. $\mathrm{m}^{2}$ ) (Table 5) was rice husk cover, followed by ryegrass straw + millet; which were higher than the other treatments, which according to Silva et al. (2006), may be related to a more favorable environment in terms of the variety of microhabitats and resource supply. The low density of macrofauna individuals observed in treatments with natural cover, shading cover and sawdust may be related to the reduced amount of soil OM. Similar results were found by Barros et al. (2002) and Merlim et al. (2005) who verified that macrofauna was altered when the level of soil attributes decreased.

Treatments with natural cover, Curauá fiber and manual weeding had the lowest species richness value (Table 5), while the highest diversity values and evenness indexes were found for ryegrass + millet and rice husk cover. The management of these systems favors better soil coverage with greater OM contribution. $\quad \mathrm{T} \mathrm{h}$ e presence of soil cover contributes to the increase of energy availability and requires new habitats, which are favorable for the colonization of edaphic organisms and benefit the ecological sustainability of agro-ecological production systems (SILVA et al., 2007).

However, soil management in orchard areas should be adapted to provide permanent soil cover, which could be beneficial considering the ecological aspects (FADINI et al., 2001).

Table 1 . Weed dry mass production $\left(\mathrm{g} / 0.5 \mathrm{~m}^{2}\right)$ according 
to the soil coverage in the evaluation at 75 days after placement of the coverings mulching in Hosui cultivar pear orchard for the 2015/16 and 2016/17 cycles. Cruz Machado, PR, Brazil. 2017.

\begin{tabular}{lll}
\hline & Weed dry mass \\
\cline { 2 - 3 } & \multicolumn{2}{c}{ Cycles } \\
\hline Treatments & $\mathbf{2 0 1 5 / 1 6}$ & \multicolumn{2}{c}{$\mathbf{2 0 1 6} / \mathbf{1 7}$} \\
\hline Natural cover & $131.8 \mathrm{a}^{*}$ & $107.4 \mathrm{ab}$ \\
Ryegrass + millet & $62.3 \mathrm{~b}$ & $64.6 \mathrm{~b}$ \\
Pine sawdust & $137.2 \mathrm{a}$ & $70.7 \mathrm{~b}$ \\
Shading cover & $111.0 \mathrm{a}$ & $52.8 \mathrm{~b}$ \\
Rice husk & $156.0 \mathrm{a}$ & $141.9 \mathrm{a}$ \\
Curauá fiber & $0 \mathrm{c}$ & $0 \mathrm{c}$ \\
Weeding & $0 \mathrm{c}$ & $0 \mathrm{c}$ \\
\hline
\end{tabular}

*Different letters in the column indicate significant difference by the Student Newman Keuls test at a 5\% probability level.

Table 2. Plant height, stem diameter for Hosui cultivar pear trees in the 2015/16 and 2016/17 cycles and Chlorophyll index (SPAD) 2016/17 under different soil coverages. Cruz Machado, PR, Brazil. 2017.

\begin{tabular}{lllllllll}
\hline & \multicolumn{3}{c}{ Plant height } & \multicolumn{3}{c}{ Plant diameter } & \multicolumn{3}{c}{ Chlorophyll index (SPAD) 2016/17 } \\
\cline { 2 - 8 } Treatments & \multicolumn{1}{c}{$2015 / 16$} & $2016 / 17$ & $2015 / 16$ & $2016 / 17$ & Nov/16 & Dez/16 & Jan/17 \\
\hline Natural cover & $1.17 \mathrm{bc}^{*}$ & $1.98 \mathrm{c}$ & $17.4 \mathrm{bc}$ & $25.4 \mathrm{ab}$ & $42.9 \mathrm{~d}$ & $41.4 \mathrm{c}$ & $41.8 \mathrm{~d}$ \\
Ryegrass + millet & $1.22 \mathrm{~b}$ & $2.24 \mathrm{ab}$ & $17.4 \mathrm{bc}$ & $27.1 \mathrm{ab}$ & $53.0 \mathrm{a}$ & $50.0 \mathrm{a}$ & $46.9 \mathrm{~b}$ \\
Pine sawdust & $1.13 \mathrm{c}$ & $1.82 \mathrm{c}$ & $16.5 \mathrm{c}$ & $24.0 \mathrm{~b}$ & $43.2 \mathrm{~d}$ & $41.5 \mathrm{c}$ & $41.6 \mathrm{~d}$ \\
Shading cover & $1.21 \mathrm{ab}$ & $2.32 \mathrm{~b}$ & $17.6 \mathrm{bc}$ & $28.3 \mathrm{ab}$ & $41.7 \mathrm{e}$ & $41.8 \mathrm{c}$ & $42.5 \mathrm{~d}$ \\
Rice husk & $1.19 \mathrm{bc}$ & $2.20 \mathrm{ab}$ & $17.5 \mathrm{bc}$ & $26.6 \mathrm{ab}$ & $41.9 \mathrm{e}$ & $44.7 \mathrm{~b}$ & $44.1 \mathrm{c}$ \\
Curauá fiber & $1.26 \mathrm{a}$ & $2.48 \mathrm{a}$ & $20.5 \mathrm{a}$ & $30.9 \mathrm{a}$ & $51.0 \mathrm{~b}$ & $48.4 \mathrm{a}$ & $51.9 \mathrm{a}$ \\
Weeding & $1.25 \mathrm{a}$ & $2.28 \mathrm{ab}$ & $18.9 \mathrm{~b}$ & $28.6 \mathrm{ab}$ & $49.4 \mathrm{c}$ & $49.8 \mathrm{a}$ & $51.3 \mathrm{a}$ \\
\hline CV(\%) & 21.53 & 11.08 & 18.72 & 14.53 & 11.45 & 8.40 & 8.35 \\
\hline
\end{tabular}

"Different letters in the column indicate significant difference by Student Newman-Keuls test at $5 \%$ probability.

Table 3. Nitrogen $(\mathrm{N})$, phosphorus $(\mathrm{P})$, calcium $(\mathrm{Ca})$, potassium $(\mathrm{K})$, magnesium $(\mathrm{Mn})$, copper $(\mathrm{Cu})$, iron $(\mathrm{Fe})$, manganese $(\mathrm{Mn})$ and zinc $(\mathrm{Zn})$, in Hosui cultivar pear tree leaves in the second cycle after planting according to the different soil coverages. Cruz Machado, PR, Brazil. 2017.

\begin{tabular}{|c|c|c|c|c|c|c|c|c|c|}
\hline \multirow[b]{2}{*}{ Treatments } & $\mathrm{N}$ & $\mathrm{P}$ & $\mathrm{Ca}$ & K & $\mathrm{Mg}$ & $\mathrm{Cu}$ & $\mathrm{Fe}$ & $\mathrm{Mn}$ & $\mathrm{Zn}$ \\
\hline & \multicolumn{5}{|c|}{ 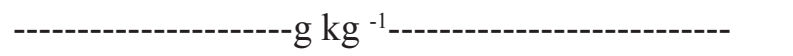 } & \multicolumn{4}{|c|}{ 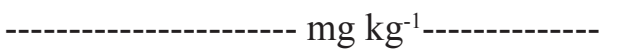 } \\
\hline Natural cover & $26.0^{\text {ns }}$ & $3.1 \mathrm{ab}^{*}$ & $14.6^{\mathrm{ns}}$ & $19.0^{\mathrm{ns}}$ & $1.4^{\mathrm{ns}}$ & $2.1 \mathrm{~b}$ & $36.7 \mathrm{~b}$ & $11.7 \mathrm{bc}$ & $26.5 \mathrm{ab}$ \\
\hline Ryegrass + millet & 31.5 & $2.9 \mathrm{ab}$ & 14.6 & 19.5 & 1.7 & $6.1 \mathrm{ab}$ & $39.6 \mathrm{ab}$ & $7.3 \mathrm{bc}$ & $50.1 \mathrm{a}$ \\
\hline Pine sawdust & 28.7 & $3.5 \mathrm{ab}$ & 13.1 & 19.0 & 1.6 & $4.7 \mathrm{ab}$ & $51.3 \mathrm{ab}$ & $7.3 \mathrm{bc}$ & $39.7 \mathrm{ab}$ \\
\hline Shading cover & 29.6 & $2.8 \mathrm{~b}$ & 15.1 & 17.9 & 1.8 & $4.9 \mathrm{ab}$ & $48.1 \mathrm{ab}$ & $19.8 \mathrm{~b}$ & $44.1 \mathrm{~b}$ \\
\hline Rice husk & 30.2 & $3.4 \mathrm{ab}$ & 12.9 & 18.4 & 1.6 & $3.4 \mathrm{ab}$ & $44.7 \mathrm{ab}$ & $6.5 \mathrm{bc}$ & $54.5 \mathrm{a}$ \\
\hline Curauá fiber & 30.4 & $4.0 \mathrm{a}$ & 16.0 & 17.9 & 1.7 & $5.0 \mathrm{ab}$ & $70.3 \mathrm{a}$ & $25.5 \mathrm{a}$ & $19.3 \mathrm{ab}$ \\
\hline Weeding & 30.5 & $3.3 \mathrm{ab}$ & 12.1 & 17.1 & 1.6 & $7.3 \mathrm{a}$ & $66.4 \mathrm{ab}$ & $2.9 \mathrm{c}$ & $7.00 \mathrm{c}$ \\
\hline $\mathrm{CV}(\%)$ & 14.2 & 15.2 & 19.6 & 10.9 & 12.9 & 20.8 & 27.3 & 25.0 & 24.4 \\
\hline
\end{tabular}

${ }^{*}$ Different letters in the column indicate significant difference by Student Newman-Keuls test at 5\% probability. ${ }^{\text {ns }}$ - not significant.

Table 4. Soil chemical attributes (organic matter-MO; $\mathrm{pH} \mathrm{CaCl}{ }_{2}$; phosphorus-P; aluminum-Al; calcium-Ca and potassium-K) for different soil coverages in the depths of $0-20 \mathrm{~cm}$ in the planting rows of Hosui cultivar pear trees. 
Cruz Machado, PR, Brazil. 2017.

\begin{tabular}{|c|c|c|c|c|c|c|c|}
\hline Atributos & $\begin{array}{l}\text { O.M. } \\
\mathrm{g} \mathrm{dm}^{-3}\end{array}$ & $\begin{array}{c}\mathrm{pH} \\
\mathrm{Cacl}_{2}\end{array}$ & $\begin{array}{c}\mathrm{P} \\
\mathrm{mg} \mathrm{dm}{ }^{-3}\end{array}$ & \multicolumn{3}{|c|}{$\mathrm{cmol}_{\mathrm{c}} \mathrm{dm}^{-3}$} & $\mathrm{Mg}$ \\
\hline Tratamentos & & & & & & & \\
\hline Natural cover & $30.2 b^{*}$ & $5.2 \mathrm{ab}$ & $1.9 \mathrm{~b}$ & $0.07^{\mathrm{ns}}$ & $4.8 \mathrm{c}$ & $0.4 \mathrm{c}$ & $1,02 \mathrm{c}$ \\
\hline Ryegrass + millet & $32.9 \mathrm{~b}$ & $5.6 \mathrm{a}$ & $5.0 \mathrm{a}$ & 0.05 & $8.2 \mathrm{~b}$ & $1.2 \mathrm{a}$ & $1,49 \mathrm{ab}$ \\
\hline Pine sawdust & $28.3 \mathrm{c}$ & $5.1 \mathrm{ab}$ & $2.3 \mathrm{~b}$ & 0.07 & $9.8 \mathrm{a}$ & $0.8 \mathrm{~b}$ & $1,28 \mathrm{ab}$ \\
\hline Shading cover & $30.1 \mathrm{~b}$ & $4.1 \mathrm{c}$ & $1.1 \mathrm{c}$ & 0.05 & $9.7 \mathrm{a}$ & $0.8 \mathrm{~b}$ & $1,49 \mathrm{ab}$ \\
\hline Rice husk & $40.1 \mathrm{a}$ & $5.5 \mathrm{a}$ & $2.3 \mathrm{~b}$ & 0.03 & $10.3 \mathrm{a}$ & $0.9 \mathrm{~b}$ & $1,75 \mathrm{a}$ \\
\hline Curauá fiber & $38.2 \mathrm{ab}$ & $5.2 \mathrm{ab}$ & $3.1 \mathrm{~b}$ & 0.02 & $11.5 \mathrm{a}$ & $0.7 \mathrm{~b}$ & $1,82 \mathrm{a}$ \\
\hline Weeding & $37.8 \mathrm{ab}$ & $5.3 \mathrm{~b}$ & $2.0 \mathrm{~b}$ & 0.06 & $11.7 \mathrm{a}$ & $0.7 \mathrm{~b}$ & $1,58 b$ \\
\hline $\mathrm{CV}(\%)$ & 15.3 & 11.2 & 12.6 & 10.5 & 23.9 & 22.7 & 26,17 \\
\hline
\end{tabular}

"Different letters in the column indicate significant difference by Student Newman-Keuls test at $5 \%$ probability. ${ }^{\text {ns }}$ - not significant.

Table 5. Density (ind. $\mathrm{m}^{2}$ ) number of individuals per unit area, total richness, Shannon diversity index and Pielou evenness index of the soil macrofauna under different coverings in the planting rows of Hosui cultivar pear trees. Cruz Machado, PR, Brazil. 2017.

\begin{tabular}{|c|c|c|c|c|}
\hline & Number of individuals $\left(\mathrm{m}^{2}{ }^{2}\right)$ & Total richness & Shannon Index & Pielou Index \\
\hline Natural cover & $3.7 \mathrm{c}^{*}$ & $3 \mathrm{~b}$ & $0.34 \mathrm{~d}$ & $0.21 \mathrm{c}$ \\
\hline Ryegrass + millet & $13.2 \mathrm{~b}$ & $4 \mathrm{a}$ & $0.77 \mathrm{a}$ & $0.38 \mathrm{~b}$ \\
\hline Pine sawdust & $4.5 \mathrm{c}$ & $4 \mathrm{a}$ & $0.40 \mathrm{~d}$ & $0.20 \mathrm{c}$ \\
\hline Shading cover & $4.0 \mathrm{c}$ & $4 \mathrm{a}$ & $0.37 \mathrm{~d}$ & $0.19 \mathrm{c}$ \\
\hline Rice husk & $17.5 \mathrm{a}$ & $4 \mathrm{a}$ & $0.68 \mathrm{~b}$ & $0.68 \mathrm{a}$ \\
\hline Curauá fiber & $7.7 \mathrm{bc}$ & $3 \mathrm{~b}$ & $0.57 \mathrm{c}$ & $0.36 \mathrm{~b}$ \\
\hline Weeding & $6.7 \mathrm{bc}$ & $3 \mathrm{~b}$ & $0.50 \mathrm{c}$ & $0.32 \mathrm{~b}$ \\
\hline
\end{tabular}

*Different letters in the column indicate significant difference by Student Newman-Keuls test at $5 \%$ probability.

\section{Conclusions}

Curauá fiber and azevem + millet straw control weeds in the orchard, promoting better initial development of pear Hosui cultivar, providing higher levels of nutrients in pear leaves, attributes and chemical attributes of soil fertility and macrofauna rates under the conditions of the experiment, respectively.

\section{Acknowledgements}

To the Coordination and Improvement of Higher Level or Education Personnel for the scholarship granted to the first author.

\section{References}

ALMEIDA, F.S. de. Efeitos alelopáticos de resíduos vegetais. Pesquisa Agropecuária Brasileira, Brasília, DF, v. 26, n. 2, p. 221-236, 1991.

ANDERSON, J.M.; INGRAM, J.S.I. Tropical soil biological and fertility: a handbook of methods. $2^{\text {nd }}$ ed. Wallingford: CAB International, 1993. 221p.

BARROS, E.; PASHANASI, B.; CONSTANTINO, R.; LAVELLE, P. Effects of land-use system on the soil macrofauna in western Brazilian Amazonia. Biology and Fertility of Soils, Berlin, v.35, p.338- 347, 2002.

BASSO, C.; FREIRE, C.J.S.; SUZUKI, A. Solos, adubação e nutrição. In: QUEZADA, A.C.; NAKASU, B.H.; HERTER, F.G. Pêra: produção. Brasília: Embrapa, 2003. p.55-67. 
BEHRENS, D. Cuaruá-faser-eine Pflansenfaser als Konstruktionswerkstoff. Berlin: Verlag, 1999. p.159178 .

BELTRAMI, L.V.R.; SCIENZA, L.C.; ZATTERA, A.J. Efeito do tratamento alcalino de fibras de curauá sobre as propriedades de compósitos de matriz biodegradável. Polímeros, São Paulo, v. 24, n. 3, p. 388394, 2014.

BENBROOK, C. Impacts of genetically engineered crops on pesticide use in the United States: The first thirteen years. The Organic Center, Washington, v. 69, 2009.

BOTELHO, R.V.; MÜLlER, M.M.L.; BASSO, C; SUZUKI, A. Estado nutricional de diferentes cultivares de pereira nas condições edafoclimáticas de Guarapuava-PR. Revista Brasileira de Fruticultura, Jaboticabal, v.32, n.3, p.884-891, 2010.

BRASIL. Instrução normativa 077/1999. Normas de produção, tipificação, processamento, envase, distribuição, identificação e de certificação da qualidade para os produtos orgânicos de origem vegetal e animal. Brasília: Ministério da Agicultura, Pecuária e Abastecimento, 1999. Disponível em: http://www.agricultura.gov.br. Acesso em: 07 mar. 2018.

BRUNETTO, G.; NAVA, G. AMBROSINI, V.G.; COMIN, J.J.; KAMINSKI, J. The pear tree response to phosphorus and potassium fertilization. Revista Brasileira de Fruticultura, Jaboticabal, v.37, n.2, p.507- 516, 2015.

CARVALHO, J.E.B. de; VARGAS, L. Manejo e controle de plantas daninhas em frutíferas. In: VARGAS, L.; ROMAN, E.S. Manual de manejo e controle de plantas daninhas. Bento Gonçalves: EMBRAPA/CNPUV, 2004. $652 \mathrm{p}$.

CARVAlHO, W.; CANILHA, L.; FERRAZ, A.; MILAGRES, A.M.F. Uma visão sobre a estrutura, composição e biodegradação da madeira. Química Nova, São Paulo, v. 32, n. 8, p. 2191-2195, 2009.

CENTELLAS-QUEZADA, A.; NAKASU, B.H.; HERTER, F.G. (ed.). Pera: produção. Brasília: Embrapa, 2003. 105p. (Frutas do Brasil, 46).

CQFS - Comissão de Química e Fertilidade do Solo. Manual de adubação e calagem para os estados do Rio Grande do Sul e de Santa Catarina. 10.ed. Porto Alegre: SBCS - Núcleo Regional Sul/UFRGS, 2004. 400 p.

EMBRAPA- Empresa Brasileira de Pesquisa Agropecuária. Manual de análise de solo, plantas e fertilizantes. 2 . ed. Brasilia, DF, 2009. 627 p.
EMBRAPA - Empresa Brasileira de Pesquisa Agropecuária. Sistema brasileiro de classificação de solos. 3.ed. Brasília, DF, 2013. 353p.

FADINI, L.A.M.; REGINA, M.A.; FRÁGUAS, J.C.; LOUZADA, J.N.C. Efeito da cobertura vegetal sobre a abundância e diversidade de inimigos naturais de pragas em vinhedos. Revista Brasileira de Fruticultura, Jaboticabal, v.23, n.3, p.573-576, 2001.

FAO - Food Agriculture Organization of The United Nations. Faostat database prodstat. Rome, 2016. Disponível em: http://faostat.fao.org/. Acesso em: $11 \mathrm{dez}$. 2016.

FERREIRA, D.F. Sisvar: a guide for its bootstrap procedures in multiple comparisons. Ciência e Agrotecnologia, Lavras, v. 38, n. 2, p. 109-112, 2014.

GOH, K.M.; PEARSON, D.R.; DALY, M.J. Effects of apple orchard production systems on some important soil physical, chemical and biological quality parameters. Biological Agriculture and Horticulture, Abingdon, v.18, n.3, p.269-292, 2000.

GOMES JR, F.G.; CHRISTOFFOLETI, P.J. Biologia e manejo de plantas daninhas em áreas de plantio direto. Planta Daninha, São Paulo, v. 26 n.4, 789-798, 2008.

LEITE JÚNIOR, R.P.; MOHAN, S.K. Integrated management of citrus bacterial canker disease caused by Xanthomonas campestris pv. citri in the State of Paraná, Brazil. Crop protection, Parma, USA, v. 9, p.3-7, 1990. Disponível em: http://www.sciencedirect.com/. Acesso em: 11 dez. 2017.

MARTINS, D. Estudo do efeito de coberturas mortas de inverno e da aplicação de herbicidas sobre a comunidade infestante da cultura do milho. In: CONGRESSO LATINOAMERICANO DE MALEZAS, 12., 1995, Montevidéo, Resumenes [...]. Montevidéo: ALAM, 1995. p. 76.

MATHEIS, H.A.S.M.; AZEVEDO, F.A.; VICTORIA FILHO, R. Adubação verde no manejo de plantas daninhas na cultura de citros. Laranja, Cordeirópolis, v.27, n.1, p.101-110, 2006.

MENDONÇA, E.S. Oxidação da matéria orgânica e sua relação com diferentes formas de alumínio de Latossolos. Revista Brasileira de Ciência do Solo, Campinas, v.19, p.25-30, 1995. 
MERLIM, A. de O.; GUERRA, J.G.M.; JUNQUEIRA, R.M.; AQUINO, A.M. de. Soil macrofauna in cover crops of figs grown under organic management. Scientia Agricola, Piracicaba, v.62, p.57-61, 2005.

MESCHEDE, D.K. Evaluation of weed suppression using different crop covers under Brazilian cerrado soil conditions. Planta Daninha, Viçosa, MG, v. 25, n. 3, p. 465-471, 2007.

ODUM, E.P. Ecologia. Rio de Janeiro: Guanabara, 1988. $434 \mathrm{p}$.

OLIVEIRA, F.T.D.; MENDONÇA V.; HAFLE, O.M.; MOREIRA, J.N.; MARACAJÁ, P.B., AUGUSTO, J.; LOPES, J.D.A. Fontes orgânicas e doses de fosfato natural na produção de porta-enxertos de goiabeira. Revista Agropecuaria Cientifica no Semiárido, Campina Grande, v.9, n.1, p.36-42, 2013.

PAVAN, M.A.; CARAMORI, P.H.; ANDROCIOLI FILHO, A.; SCHOLZ, M.F. Manejo da cobertura do solo para formação e produção de uma lavoura cafeeira. I. Influência na fertilidade do solo. Pesquisa Agropecuária Brasileira, Brasília, DF, v. 21, n. 2, p. 187-192, 1986.

PAVINATO, P.S.; ROSOLEM, C.A. Disponibilidade de nutrientes no solo: decomposição e liberação de compostos orgânicos de resíduos vegetais. Revista Brasileira de Ciência do Solo, Viçosa, MG, v. 32, n. 3, p. 911-920, 2008.

PELIZZA, T.R.; MAFRA, A.L.; AMARANTE, C.V.T.; NOHATTO, M.A.; VARGAS, L. Coberturas do solo e crescimento da macieira na implantação de um pomar em sistema orgânico de produção. Revista Brasileira de Fruticultura, Jaboticabal, v. 31, n. 3, p. 739-748, 2009.

PITELLI, R. A. Dinâmica de plantas daninhas no sistema de plantio direto. In: SIMPÓSIO SOBRE HERBICIDAS E PLANTAS DANINHAS, 1., 1997, Dourados. Resumos [...]. Dourados: Embrapa-CPAO, 1997. p. 50-61.

RAGOZO, C.R.; LEONEL, S.; CROCCI, A.J. Adubação verde em pomar cítrico. Revista Brasileira de Fruticultura, Jaboticabal, v. 28, n. 1, p. 69-72, 2006.
RHEINHEIMER, D.D.S.; ANGHINONI, I. Distribution of inorganic phosphorus fraction in soil management systems. Pesquisa Agropecuária Brasileira, Brasília, DF, v. 36, n. 1, p. 151-160, 2001.

ROSA, C.C.; MOREIRA, D.D.C.; BILCATI, G.K. Estudo das propriedades físicas da fibra de Curauá. In: CONGRESSO BRASILEIRO DE EDUCAÇÃO EM ENGENHARIA, 11., 2012. Belem. Anais [...]. Disponível em: http://www.abenge.org.br/cobenge/arquivos/7/ artigos/104163.pdf/. Acesso em: 15 dez. 2017.

SILVA, R.F.; TOMAZI, M.; PEZARICO, C.R.; AQUINO, A.M.; MERCANTE, F.M. Macrofauna invertebrada edáfica em cultivo de mandioca sob sistemas de cobertura do solo. Pesquisa Agropecuária Brasileira, Brasília, DF, v.42, p.865-871, 2007.

SILVA, R.F.; AQUINO, A.M.; MERCANTE, F.M.; GUIMARÃES, M.F. Macrofauna invertebrada do solo sob diferentes sistemas de produção em Latossolo da Região do Cerrado. Pesquisa Agropecuária Brasileira, Brasília, DF, v. 41, p. 697-704, 2006.

SIMEPAR, Sistema Meteorológico do Paraná -. Clima 2012.http://www.simepar.br/site. 10 Jan. 2017.

SOUZA, J.L.; GUIMARÃES, G.P. Alterações químicas THEISEN, G.; VIDAL, R.A. Efeito da cobertura do solo com resíduos de aveia-preta nas etapas do ciclo de vida do capim marmelada. Planta Daninha, Londrina, v. 17, n. 2, p. 189-196, 1999.

VOLL, E.; GAZZIERO, D.L.P.; BRIGHENTI, A.M.; ADEGAS, F.S.; GAUDÊNCIO, C.D.A.; VOLL, C.E. A dinâmica das plantas daninhas e práticas de manejo. Londrina: Embrapa Soja, 2005.

ZAMBOLIM, L.; VENTURA, J.A.; ZANÂO JR, L.A. Influência da nutrição mineral no controle de doenças de plantas. Viçosa: UFV, 2012. 321p.

ZINN, Y.L.; MARRENJO, G.J.; SILVA, C.A. Soil C: $\mathrm{N}$ ratios are unresponsive to land use change in Brazil: A comparative analysis. Agriculture, Ecosystems e Environment, Amsterdam,v. 255, p. 62-72, 2018. 